\title{
Proposed Corrosion Control Method for Fire Fighting Systems in Oil Fields
}

\author{
M. F. Shehata*, N. A. Abdel Ghany ${ }^{\#}$ and A. A. El Hosary \\ National Research Center, Cairo, Egypt.
}

\begin{abstract}
7 HE FIRE fighting systems are found in all oil production and processing fields. The water used in these systems is mostly underground-, sea-, fresh- and could be formation - water. The corrosion control of these systems is achieved by injection of corrosion inhibitor, biocide and oxygen scavenger chemicals, either separately or mixed (multifunction). In the present paper, replacement of the currently used multifunction chemicals by $\mathrm{Ca}(\mathrm{OH})_{2}$ is proposed as more economic and effective corrosion control regime. Inhibition in this case depends on increasing the $\mathrm{pH}$ of the water to about 12 leading to deposition of the calcium ions of the water as carbonate and/or sulfate layer on the tank surface. This barrier layer in addition to the passivity of the steel surface in this basic water could achieve the required corrosion control. The result obtained, compared with the currently used multifunction chemicals indicate more higher corrosion inhibition of the proposed method for both general and local corrosion.
\end{abstract}

Fire fighting systems (F.F.S.) are found in all production and processing petroleum companies. These systems generally use sea water, underground water, fresh water and some may use oil-associated (formation water). They are treated with corrosion inhibitors, oxygen scavengers and biocides, either separate or in multifunction form to control corrosion and biofouling of the mild steel tanks and pipes, in addition to cathodic protection (sacrificial anodes).

The corrosion control of steel in saturated $\mathrm{Ca}(\mathrm{OH})_{2}$ solution has been severally reported ${ }^{(1-3)}$. The inhibition by $\mathrm{Ca}(\mathrm{OH})_{2}$ depends on increasing the $\mathrm{pH}$ of the water to about 12 leading to deposition a barrier layer of calcium ions of the water as carbonate and /or sulfate layer on the tank surface ${ }^{(2)}$.

In this paper, more simple and economic method of control is proposed. This method depends on saturated calcium hydroxide and corrosion inhibitor instead of the three additives. The corrosion control of steel in saturated $\mathrm{Ca}(\mathrm{OH})_{2}$ solution has been severally reported ${ }^{(1-3)}$.

\section{Experimental}

Carbon steel was tested in water sample used in fire fighting system of a

\footnotetext{
*Corresponding authors Emails: mshehata1968@ yahoo.com

\#na_manakhly@yahoo.co.uk; na.abdelghany@nrc.sci.eg
} 
petroleum production company, before injection. The analysis of this water is given in Table 1. The chemical composition of the used steel is given in Table 2.

TABLE 1. Analysis of the used water.

\begin{tabular}{|l|c|c|c|c|c|c|c|c|c|l|}
\hline \multicolumn{1}{|c|}{ Item } & $\mathbf{N a}^{+}$ & $\mathbf{K}^{+}$ & $\mathbf{M g}^{++}$ & $\mathbf{C a}^{++}$ & $\mathbf{S r}^{++}$ & $\mathbf{B a}$ & $\mathbf{F e}^{++}$ & $\mathbf{C l}^{-}$ & $\mathbf{H C O}_{3}^{-}$ & $\mathbf{S O}_{4}^{2-}$ \\
\hline $\begin{array}{l}\text { Concentration } \\
(\mathrm{ppm})\end{array}$ & 1730 & 112 & 403 & 397 & 44.2 & 0.1 & 4.4 & 4120.7 & 126 & 560.6 \\
\hline
\end{tabular}

TABLE 2. Analysis of the used carbon steel.

\begin{tabular}{|l|c|c|c|c|c|c|c|c|c|c|c|c|}
\hline Element & $\mathbf{C}$ & $\mathbf{M n}$ & $\mathbf{S i}$ & $\mathbf{P}$ & $\mathbf{S}$ & $\mathbf{C u}$ & $\mathbf{C r}$ & $\mathbf{N i}$ & $\mathbf{T i}$ & $\mathbf{A l}$ & $\mathbf{M o}$ & $\mathbf{S n}$ \\
\hline Amount, $\%$ & 0.047 & 0.289 & 0.037 & 0.017 & 0.013 & 0.054 & 0.049 & 0.057 & 0.02 & 0.003 & 0.002 & 0.02 \\
\hline
\end{tabular}

The corrosion tests were conducted by weight loss and cyclic polarization methods to measure the general and pitting corrosion, respectively. The general corrosion was measured by immersing clean carbon steel coupons $(2 \times 10 \times 0.2 \mathrm{~cm})$ for five days in the test water at ambient temperature under static condition.

In the polarization tests, steel electrode with $1 \mathrm{~cm}^{2}$ subjected area was used, with Pt counter and saturated calomel electrodes. The measurements were conducted by EG\&G potentiostatlGalvanostat Model 273A.. After reaching steady potential, $\mathrm{E}_{\text {cor }}$ (about $40 \mathrm{~min}$.), the pitting susceptibility was characterized by means of cyclic anodic polarization curves. A potential scanning rate of 0.2 $\mathrm{mV} / \mathrm{Sc}$ was used ${ }^{(4)}$. The current limit for reversing the potential scan was $10^{-3}$ $\mathrm{A} / \mathrm{cm}^{2}$. The pitting potential $\left(\mathrm{E}_{\mathrm{p}}\right)$ was defined as the potential value at which the current density sharply rises. This polarization technique has been widely used to study the corrosion of carbon steel and other steels in alkaline solutions ${ }^{(3,5,6)}$.

\section{Results and Discussion}

\section{General corrosion}

The corrosion rate values of steel in the F.F.S. water alone (C.R.Bl) and in saturated $\mathrm{Ca}(\mathrm{OH})_{2}$ in water ( $\mathrm{pH}$ about 12) (C.R. Inh.) were measured. From these values, the corrosion inhibition was calculated as:

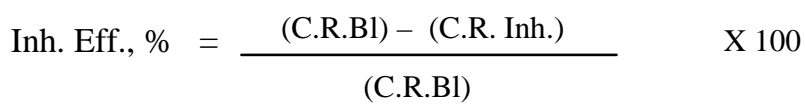

The results are given in Table 3 .

TABLE 3. General corrosion of carbon steel in the F.F.S. water.

\begin{tabular}{|l|c|c|}
\hline \multicolumn{2}{|c|}{ Corrosion rate, mpy } & \multirow{2}{*}{ \% Inhibition } \\
\hline Water alone & $\mathrm{Ca}(\mathrm{OH})_{2}$ sat. water & 83 \\
\hline 3.1 & 0.53 & 83 \\
\hline
\end{tabular}

The results show saturation with $\mathrm{Ca}(\mathrm{OH})_{2}$ achieved high corrosion inhibition

Egypt. J. Chem. 59, No.6 (2016) 
for steel ( $83 \%$ ), which is expected. This is also seen from the surface of the steel coupon immersed 15 days in the test waters (Fig. 1).
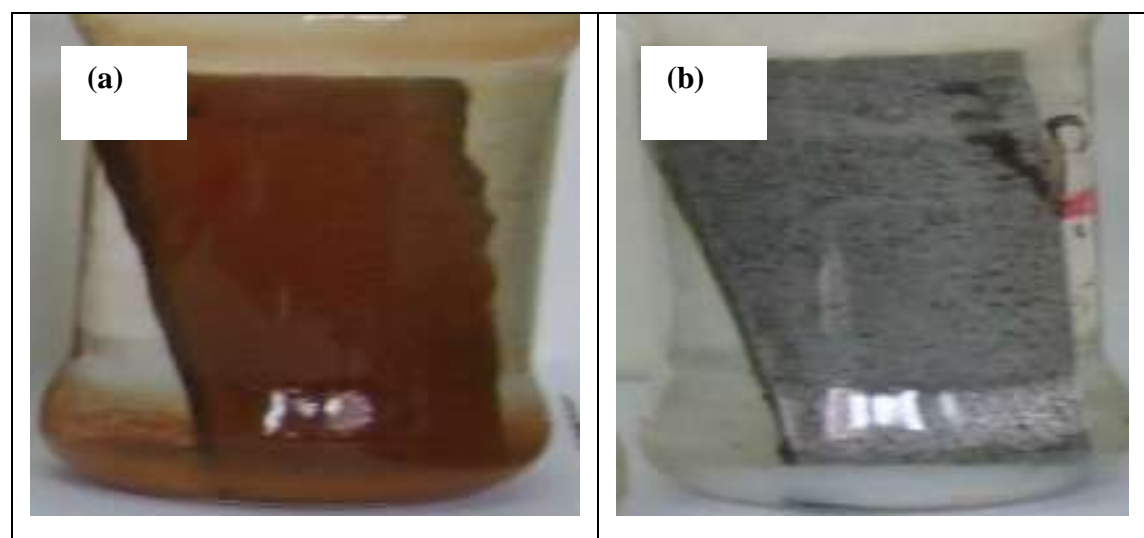

Fig. 1. Photos of the surface of steel coupons immersed for two weeks in the test water in absence (a) and presence of $\mathrm{Ca}(\mathrm{OH})_{2}(b)$.

From these results, it could be suggested that in presence of $\mathrm{Ca}(\mathrm{OH})_{2}$, there is no need for $\mathrm{O}_{2}$-scavenger. The corrosion inhibition in this system depends on the formation of a passive layer contaminated or covered with adsorbed layer of $\mathrm{Ca}$ and $\mathrm{Mg}$ sulfate and carbonate. The presence of $\mathrm{O}_{2}$ in this case could have beneficial action for the passivation process.

Concerning biocide addition, it is not sure that sulfate reducing bacteria (SRP) could live in this alkaline environment $(\mathrm{pH}=12)$, this should be confirmed.

It appears useful to refer here to the results of evaluation of multifunction chemicals previously conducted (in our Lab.) for the fire fighting system mentioned above. Examples from these results are given in following Table:

\begin{tabular}{|c|c|c|}
\hline Multifunction Chemical & $\begin{array}{c}\text { \% Inhibition of General } \\
\text { Corrosion }\end{array}$ & $\begin{array}{c}\text { \% Inhibition of Pitting } \\
\text { Corrosion }\end{array}$ \\
\hline 1 & 42 & 28 \\
\hline 2 & 64 & 61 \\
\hline 3 & 69 & 63 \\
\hline 4 & 49 & 33 \\
\hline
\end{tabular}

Comparing these results with that obtained in the present study indicate clearly more higher inhibition for the general corrosion in saturated $\mathrm{Ca}(\mathrm{OH})_{2}$ water.

\section{Pitting corrosion}

At the beginning, the detrimental action of the chloride content of the water was expected. On the other hand the other (cations and anions) contaminants with high concentration of chloride could have another action on the formed passivity and the layer 
built on the steel surface ${ }^{(7-11)}$. This means that the known effect of chloride ion on the passivity of steel in alkaline distilled water might not be the same in the present test water.

This expectation is supported by the reported mechanisms of breakdown of the passive film by chloride ions ${ }^{(6,12,13)}$. According to this mechanism, the breakdown occurs via adsorption of chloride ion on the passive film, then migration or penetration of this film to the metal surface. These two steps might be more difficult in the present formed film on the metal surface.

It thus appeared important at the beginning to conduct cyclic polarization curves for the carbon steel in distilled water saturated with $\mathrm{Ca}(\mathrm{OH})_{2}$ in presence of increasing concentrations of $\mathrm{NaCl}$. The results are given in Fig. 2. The polarization curve in the F.F.S. water is shown in Fig. 3. This figure includes also the polarization curves in the same water (F.F.S) in presence of corrosion inhibitor.

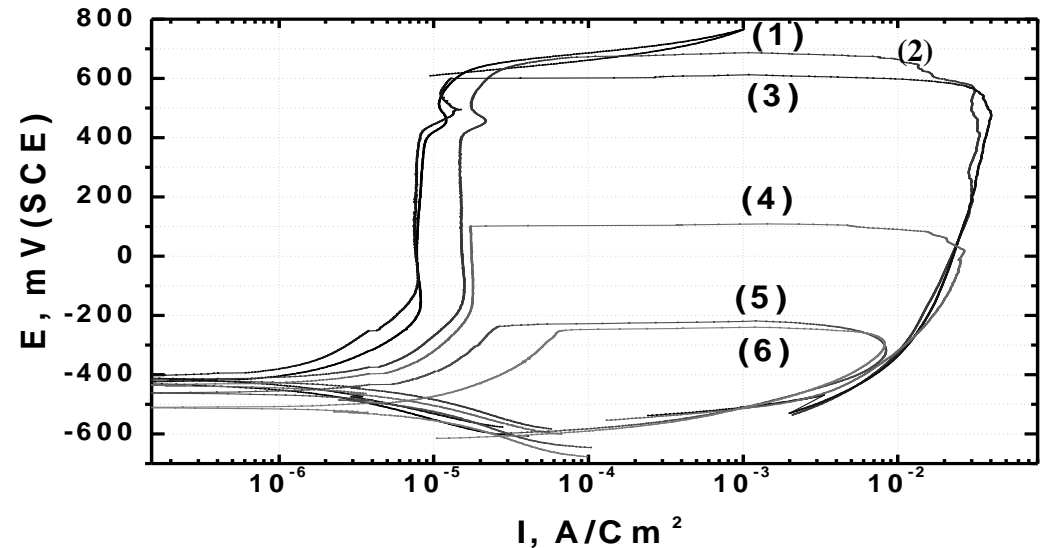

Fig. 2. Cyclic polarization curves for the steel in distilled water saturated with $\mathrm{Ca}(\mathrm{OH})_{2}$ in presence of increasing concentrations of $\mathrm{NaCl}$. $\mathrm{NaCl}, \% \mathrm{wt}, \mathbf{1}($ 0.0), 2(0.2), 3(0.4), 4 (1.0), $5(5.0), 6(10.0)$.

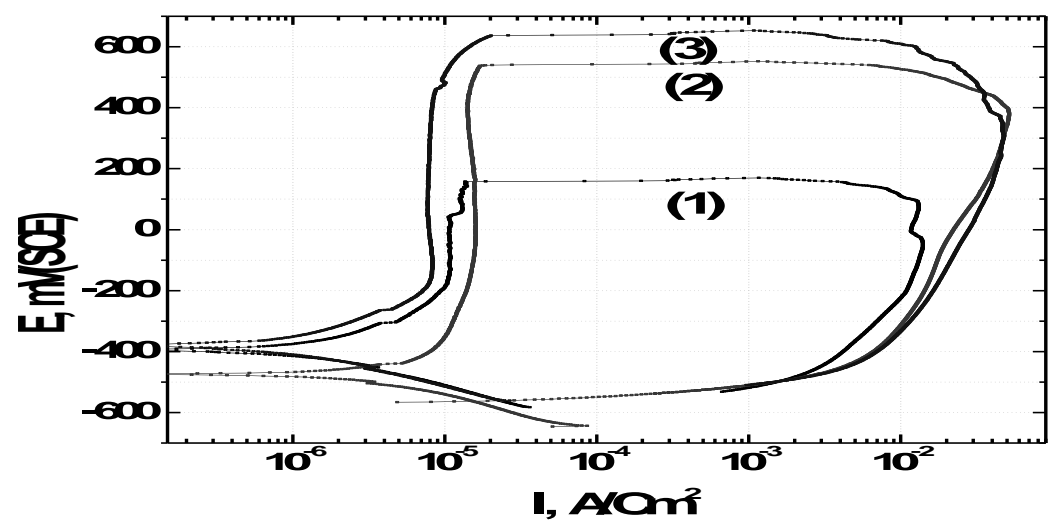

Fig. 3. Cyclic polarization curves for the carbon steel in F.F.S. water saturated with $\mathrm{Ca}(\mathrm{OH})_{2}$ in absence (1) and presence of $60 \mathrm{ppm}(2)$ and $80 \mathrm{ppm}$ molybdate inhibitor (3).

Egypt. J. Chem. 59, No.6 (2016) 
The cyclic polarization curves in saturated $\mathrm{Ca}(\mathrm{OH})_{2}$ distilled water show that in absence of chloride, no sign of attack is seen. The sudden rise in current occurred at about $660 \mathrm{mV}$ vs. SCE is caused by oxidation of $(\mathrm{OH})^{-}$ions.

$$
\left(4 \mathrm{OH}^{-}=\mathrm{O}_{2}+2 \mathrm{H}_{2} \mathrm{O}+4 \mathrm{e}\right)
$$

Addition of $0.2 \% \mathrm{NaCl}$ caused no significant shift of the potential at which the jump of the current occurs, but the curve shows hysterysis, indicating initiation of pitting. The variation of the corrosion potential $\left(\mathrm{E}_{\mathrm{corr}}\right)$, pitting potential $\left(\mathrm{E}_{\mathrm{p}}\right)$ and the difference between the two values $\left(\mathrm{E}_{\text {corr }}-\mathrm{E}_{\mathrm{p}}\right)$ with increasing $\mathrm{NaCl}$ in saturated $\mathrm{Ca}(\mathrm{OH})_{2}$ distilled water are given in Table 4 and graphically in Fig. 4.

TABLE 4. Variation of $E_{\text {corr }}, E_{p}$ and $\left(E_{c o r r}-E_{p}\right)$ in $\mathrm{Ca}(O H)_{2}$ Saturated distilled water with $\mathrm{NaCl}$ concentrations.

\begin{tabular}{|c|c|c|c|}
\hline$\% \mathbf{~ N a C l}$ & $\mathbf{E}_{\text {corr }}$ & $\mathbf{E}_{\mathbf{p}}, \mathbf{m V}$ & $\mathbf{E}_{\text {corr }}-\mathbf{E}_{\mathbf{p}}, \mathbf{m V}$ \\
\hline 0 & -400 & $660\left(\mathrm{O}_{2}\right.$ evolution $)$ & 1060 \\
\hline 0.2 & -400 & 650 & 1050 \\
\hline 0.4 & -410 & 600 & 1010 \\
\hline 1 & -420 & 80 & 500 \\
\hline 5 & -450 & -240 & 210 \\
\hline 10 & -500 & -260 & 240 \\
\hline
\end{tabular}

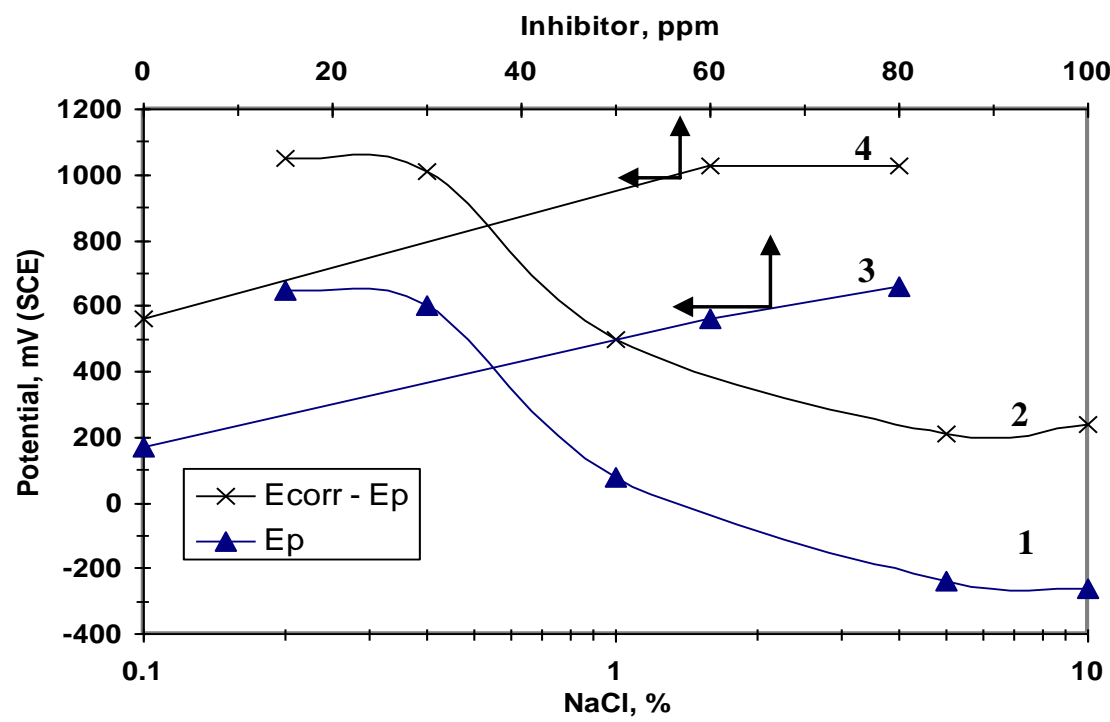

Fig. 4. The variation of Ep and (Ecorr - Ep):

Curves $(1,2)$ with $\mathrm{NaCl}$ in saturated $\mathrm{Ca}(\mathrm{OH})_{2}$ distilled water

Curves $(3,4)$ with molybdate base inhibitor in saturated $\mathrm{Ca}(\mathrm{OH})_{2}$ F.F.S.

Egypt. J. Chem. 59, No.6 (2016) 
The results of Table 4 and Fig. 4 show clearly sudden drop in both $E_{p}$ and $E_{\text {corr }}-E_{p}$ in presence of $1 \% \mathrm{NaCl}$, followed by slow variation till $5 \%$, then no significant change till $10 \%$ $\mathrm{NaCl}$. These results indicate also that the threshold concentration of $\mathrm{NaCl}$ for initiation of pitting of carbon steel in saturated $\mathrm{Ca}(\mathrm{OH})_{2}$ is about $0.4 \%$, which is in agreement with previous data $^{(11,14)}$.

The cyclic polarization curve in F.F.S. water saturated with $\mathrm{Ca}(\mathrm{OH})_{2}$, (Fig. 3), shows the sudden rise of current (pitting) occurs at $\mathrm{Ep}=170 \mathrm{mV} \mathrm{SCE}$, and $\mathrm{E}_{\text {corr }}-\mathrm{E}_{\mathrm{p}}=560 \mathrm{mV}$. This water contains chloride equivalent to $0.89 \% \mathrm{NaCl}$, in addition to about $0.15 \% \mathrm{Na}_{2} \mathrm{SO}_{4}$. The total corrosive ions in this water is about $1 \% \mathrm{NaCl}$. At this concentration in saturated $\mathrm{Ca}(\mathrm{OH})_{2}$ distilled water $\mathrm{E}_{\mathrm{p}}=80$ and $\mathrm{E}_{\mathrm{corr}}-\mathrm{E}_{\mathrm{p}}=520 \mathrm{mV}$.

The above results indicate that both $\mathrm{E}_{\mathrm{p}}$ and $\mathrm{E}_{\mathrm{cor}}-\mathrm{E}_{\mathrm{p}}$ in the test water are more positive than the corresponding values for the distilled water, by about 80 and $40 \mathrm{mV}$, respectively. These results support the previously expected beneficial action of the other constituents of the water used in fire fighting system (underground, sea and formation water).

The polarization curve of carbon steel in the F.F.S water, (Fig. 3), shows the characteristics of pitting. However, no pits could be seen visually on the electrode surface. This suggests that it is crevice corrosion. To inhibit this local attack, molybdate base inhibitor was used. Curves 2, 3 in (Fig. 3) were recorded in presence of 60 and 80 ppm from this inhibitor.

These curves show clear shifts of both $E_{p}$ and $E_{\text {corr }}-E_{p}$ to more positive potentials. In presence of $60 \mathrm{ppm}$ molybdate inhibitor, $\mathrm{E}_{\mathrm{p}}$ is shifted to $560 \mathrm{mV}$ (SCE) and $\mathrm{E}_{\text {cor }}-\mathrm{E}_{\mathrm{p}}$ to $1030 \mathrm{mV}$. Increasing the molybdate inhibitor to $80 \mathrm{ppm}$, the two parameters are shifted to 660 and $1030 \mathrm{mV}$, which are very close to the values of saturated $\mathrm{Ca}(\mathrm{OH})_{2}$ distilled water free from chloride, (Fig. 4). These results indicate a good inhibition efficiency of the used inhibitor. The high efficiency of molybdate in retarding both the general and localized corrosion of ferrous and non ferrous metals has been severally reported ${ }^{(15-18)}$. The formulation used in the present study has been previously prepared in our laboratory and tested in chemical plants ${ }^{(16)}$.

It appeared important to retest the inhibition of carbon steel in the F.F.S. water in presence of the recommended molybdate formulation ( $80 \mathrm{ppm})$.

The results of this test showed that the inhibition efficiency increased to $94 \%$ compared to $83 \%$ in absence of the inhibitor.

\section{Conclusion}

It could be concluded that the proposed method of corrosion control of fire fighting systems in oil production and processing is promising method. It basically depends on the use of saturation of the water with $\mathrm{Ca}(\mathrm{OH})_{2}$ and addition of limited concentration of molybdate base inhibitor.

Egypt. J. Chem. 59, No.6 (2016) 
The benefits of the proposed method are:

- More lower cost

- More higher inhibition for both the general and localized corrosion

- No need for both $\mathrm{O}_{2^{-}}$scavenger. The presence of $\mathrm{O}_{2}$ in this case could beneficially affect the stability of the passive film.

- No need for biocide because the present alkalinity ( $\mathrm{pH} \mathrm{12),} \mathrm{is} \mathrm{not} \mathrm{optimum} \mathrm{for}$ sulfate reducing Bactria (SRP) surviving.

\section{References}

1. Bastidas, D.M., Fernández-Jiménez, A., Palomo, A. and González, J.A., A study on the passive state stability of steel embedded in activated fly ash mortars. Corros. Sci., 50 pp. 1058-1065(2008).

2. Bautista, A., Blanco, G. and Velasco, V., Corrosion behaviour of low-nickel austenitic stainless steel reinforcements: a comparative study in simulated pore solutions. Cem. Concr. Res., 36 pp. 1922-1930(2006).

3. Fajardo, S., Bastidas, D.M., Criado, M., Romero, M. and Bastidas,J.M., Corrosion behaviour of a new low-nickel stainless steel in saturated calcium hydroxide solution. Construction and Building Materials, 25, 4190-4196(2011).

4. ASTM G61-86. Standard, test method for conducting cyclic potentiodynamic polarization measurements for localized corrosion susceptibility of iron-, nickel-, or cobalt-based alloys (2009).

5. Valcarce, M.B. and Vázquez, M., Carbon steel passivity examined in alkaline solutions: The effect of chloride and nitrite ions. Electrochim Acta, 53, 50075015(2008).

6. Hoar, T.P., The production and breakdown of the passivity of metals. Corros. Sci., 7, 341-355 (1967).

7. Goni, S. and Andrade, C., Synthetic concrete pore solution chemistry and rebar corrosion rate in the presence of chlorides. Cem. Concr. Res., 20 (4), 525-539(1990),

8. Ghods, P., Isgor, O.B., McRae, G. and Miller, T., The effect of concrete pore solution composition on the quality of passive oxide films on black steel reinforcement. Cem. Concr. Compos., 31 (1), 2-11(2009).

9. Poursaee, A. and Hansson, C.M., Reinforcing steel passivation in mortar and pore solution. Cem. Concr. Res., 37 (7), 1127-1133(2007).

10. Mammoliti, L. and Hansson, C.M., Influence of cation on corrosion behaviour of reinforcing steel in high-pH sulfate solutions. ACI Mater. J., 102 (4), 279-285(2005).

11. Ghods, P., Isgor, O.B., Brown, J.R., Bensebaa, F. and Kingston, D., XPS depth profiling study on the passive oxide film of carbon steel in saturated calcium hydroxide solution and the effect of chloride on the film properties. Applied Surface Science, 257,4669-4677(2011). 
12.Szklarska-Smialowska, Z., Review of Literature on Pitting Corrosion Published Since 1960. Corrosion, 27, 223-233(1971).

13. Vuković, M., The formation and growth of hydrous oxide film on stainless steel in alkaline solution by potential cycling. Corros. Sci. 37,111-120 (1995).

14. Ghods, P., Isgor, O.B., McRae, G. and Gu, G.P., Electrochemical investigation of chloride-induced depassivation of black steel rebar under simulated service conditions. Corros. Sci. 52 (5) 1649-1659(2010).

15. Tommaselli, M.A.G., Mariano, N.A. and Kuri, S.E., Effectiveness of corrosion inhibitors in saturated calcium hydroxide solutions acidified by acid rain components. Construction and Building Materials, 23, 328-333(2009).

16. El Hosary, A.A., Saleh, R.M. and Hegazy, H. S., Proc. of Eurocorr, Nice, France, (1996).

17. Vukasovich, M.S., Applications for the versatile molybdate inhibitor . Mater. Perform. 29, 48-51(1990).

18. Virtanen, S., Surber, B. and Ngbund, P., Influence of $\mathrm{MoO}_{4}{ }^{2-}$ anion in the electrolyte on passivity breakdown of iron. Corros Sci, 43, 1165-1177(2001).

(Received 3/8/2016; accepted $17 / 10 / 2016$ 


\section{طريقة مقترحة لتثبط التآكل فى انظمة مكافحة الحرائق فى مجال انتاج النفط}

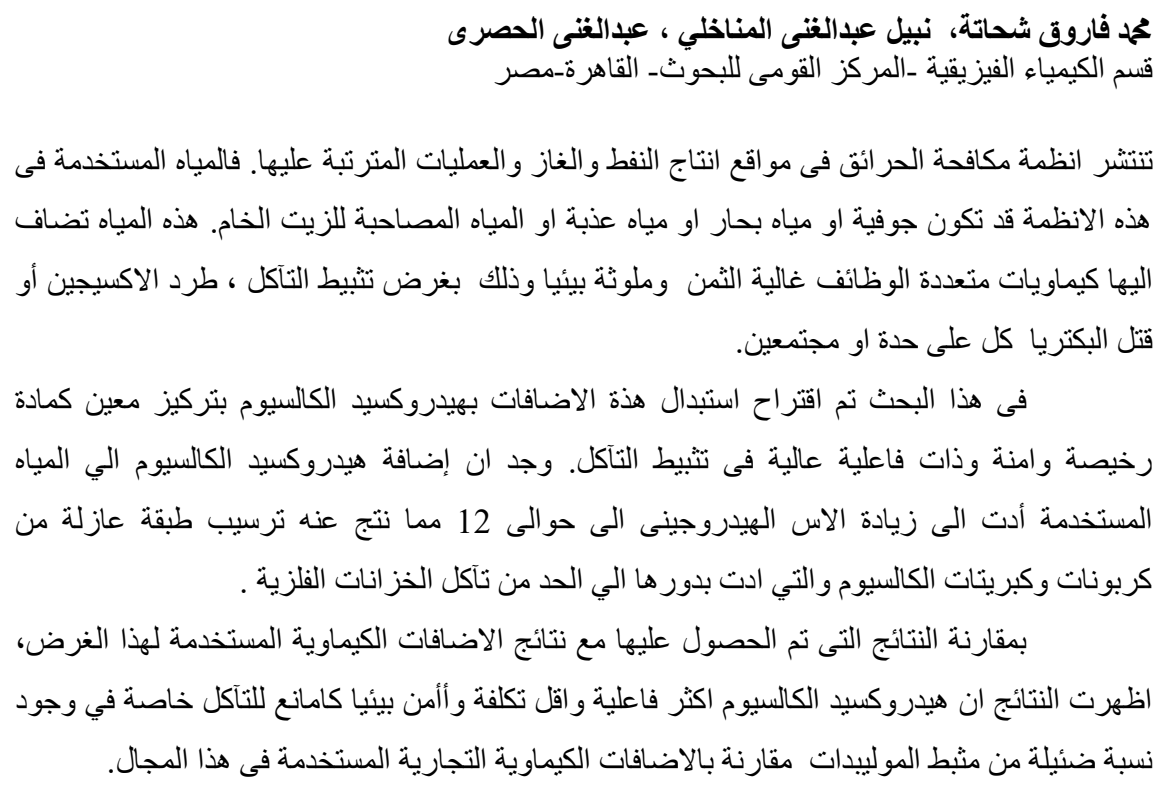

